\title{
Effects of volcanic ash on assemblage patterns and biological traits of Chironomidae in a north Andean Patagonian stream, Argentina
}

\author{
Melina Mauad $^{1 *}$, Augusto Siri ${ }^{1}$, Fernanda Montes de Oca ${ }^{2}$ and Mariano Donato ${ }^{1}$ \\ 1 Instituto de Limnología "Dr. Raúl A. Ringuelet" (ILPLA, CONICET, UNLP), Boulevard 120 y 62 s/n, La Plata, \\ Buenos Aires, Argentina \\ 2 Programa de Estudios Aplicados a la Conservación del Parque Nacional Nahuel Huapi (CENAC-APN), Fagnano 244, \\ San Carlos de Bariloche, Río Negro, Argentina
}

Received 29 June 2016; Accepted 9 November 2016

\begin{abstract}
The Puyehue-Cordón Caulle Volcanic Complex eruption occurred on June 4, 2011 (2236 m a.s.1. $\left.40^{\circ} 32^{\prime} \mathrm{S}, 72^{\circ} 7^{\prime} \mathrm{W}\right)$. As a consequence, wide areas of Argentina were covered by volcanic ash. In order to investigate the effects of ashfall on chironomid assemblages, we conducted a study at Nireco River in the southwestern part of the Natural Reserve of Nahuel Huapi National Park that crosses the city of San Carlos de Bariloche, Río Negro, Argentina. We assessed changes in chironomid assemblage attributes and 18 biological traits, by comparing pre-eruption data (December 2009 and December 2010) with post-eruption data (November 2011). Volcanic ash caused negative effects on the chironomid assemblages, where richness and density decreased significantly and the subfamilies Podonominae, Tanypodinae and Chironominae disappeared. The ordination method (principal component analysis) based on abundance of taxa and functional trait composition distinguished pre-eruption from post-eruption periods. Specific tolerance to sedimentation was related to traits mostly associated with predaceous habits such as small size, large head, retractile antennae, long prolegs, presence of ligula and long apical mandibular tooth.
\end{abstract}

Key words: Chironomidae larvae / disturbance / morphological features / South America

\section{Introduction}

Natural physical disturbances are considered important factors regulating the structure of lotic communities. Different factors have been associated with observed patterns of diversity, but the interaction between disturbance and diversity has been one of the most debated issues. Physical disturbances that affect the population structure or resource availability are postulated to have a strong influence on community structure in rivers and streams (Resh et al., 1988). Several observational and experimental studies in lotic environments indicate that disturbances reduce benthic invertebrate density and diversity, although both may recover quickly (e.g., McElravy et al., 1989). Volcanic eruptions are major disturbances with varied and complex consequences, such as the change in drainage patterns and river networks by ashfall, elimination of terrestrial vegetation and debris flows that scour stream channels (Minshall et al., 1995; Mc Dowall, 1996).

*Corresponding author: melinam@ilpla.edu.ar
Volcanic ash deposits tend to be thicker and have larger particles closer to the eruption site, and as the distance increases from the volcano, the deposits tend to be thinner. The eruption of the Volcanic Complex Puyehue-Cordón Caulle (2236 $\mathrm{m}$ a.s.1. $40^{\circ} 32^{\prime} \mathrm{S}, 72^{\circ} 07^{\prime} \mathrm{W}$ ) in Chile, on June 4, 2011 devastated over $24 \mathrm{~km}^{2}$ in southwest Río Negro and Neuquén Provinces, Argentina (Gaitán et al., 2012) (Fig. 1). On the first day, the Puyehue volcano produced $950 \mathrm{MT}$ of ash that reached $14000 \mathrm{~m}$ and much of this ash fell in Argentine Patagonia due to the predominant westerly winds (Gaitán et al., 2012).

The profile of the specific biological traits of a community offers an alternative approach for assessing the response of a stream community to disturbance, and can be expected to reflect the functional relationships between biota and environmental characteristics (Townsend et al., 1997; Dolédec et al., 2011). The inclusion of traits as alternative metrics to overcome the limitations of taxon metrics has increased in recent years. Biological traits refer to the functional attributes of the species (i.e., morphological, physiological, behavioral and ecological features) 

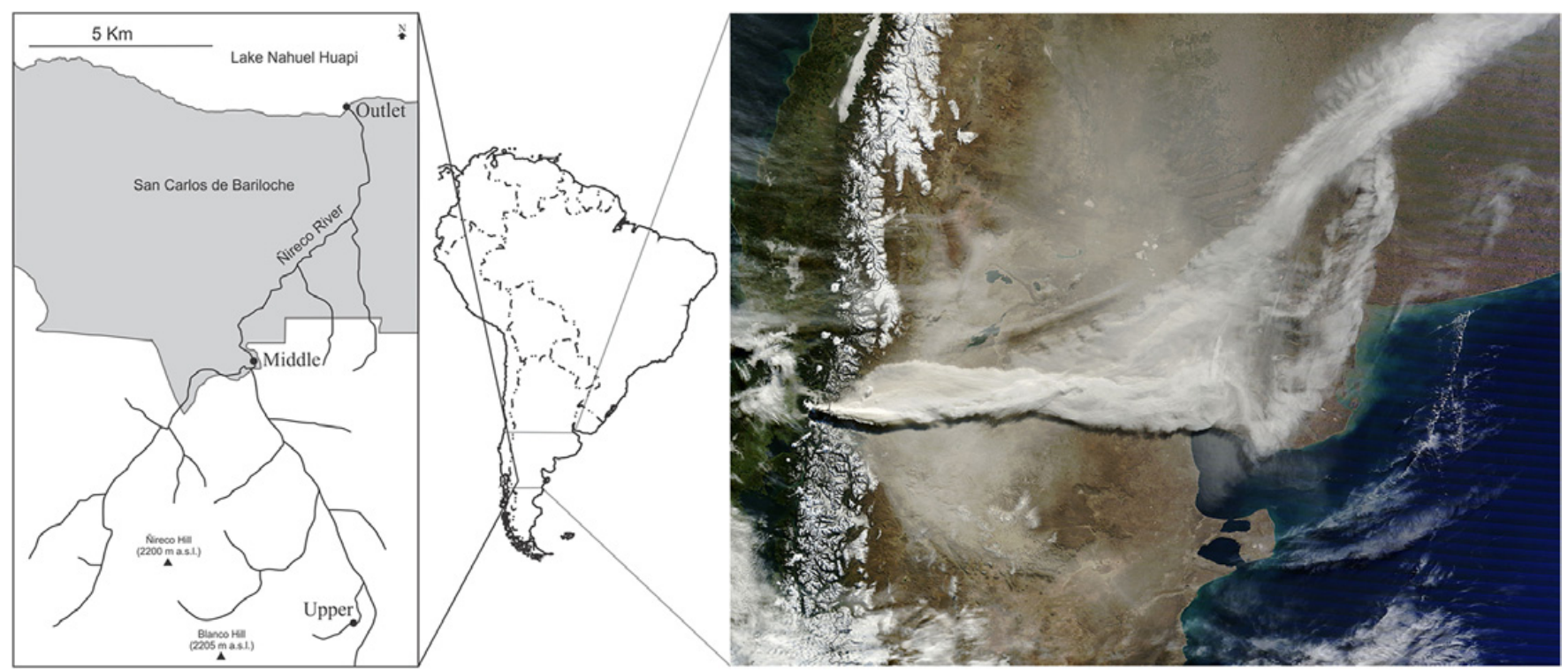

Fig. 1. Map with the three sampled sections along the Nireco River in northern Patagonia, Argentina (the gray area is San Carlos de Bariloche city); and a satellite photograph from around the eruption date (June 4, 2011).

and offer the main advantage that they can be broadly applied across biogeographic boundaries (Mcgill et al., 2006). Trait patterns can be indicators of the source of impairment because disturbances will select well-adapted species and, as a result, only those possessing relevant adaptive traits are likely to remain (Statzner et al., 2004; Buendia et al., 2013). Some studies have pointed to functional diversity as being the most versatile metric, since it not only provides an indication of species number and dominance, but also their functional role in the assemblage (Gallardo et al., 2011; Buendia et al., 2013).

This study was carried out in the Nireco River, a drainage system located in the protected area of Nahuel Huapi National Park (headwater section), and along the city of San Carlos de Bariloche, Río Negro Province, Argentina (outlet section). The particularity of the location and easy access of the water body allowed us to carry out previous studies related to environmental changes and water quality, and Chironomid fauna (García and Añón Suarez, 2007; Mauad et al., 2015, 2016). The Chironomidae family is usually very abundant and diverse, being able to respond to various environmental drivers (Cranston, 1995). After disturbances, chironomids are the dominant taxa in recovery sequences (Edwards and Sugg, 2005). Due to these previous studies in the Nireco River, the ashfall event represented a valuable opportunity to study the effects of the ash on the community of chironomids. We sampled three sections along the basin (upper, middle and outlet) affected by the volcanic disturbance at pre- and post-ash deposition. Around $1.5-3.0 \mathrm{~cm}$ of volcanic ash were deposited in the city, $100 \mathrm{~km}$ away from the volcano (Gaitán et al., 2012). We aimed to assess the changes in the attributes of Chironomidae assemblages in the river affected by heavy ash deposition, and evaluate the survival biological traits of species. Finally, we discuss the relationship between the post-ash changes found and the ash deposition and the altitudinal gradient.

\section{Materials and methods}

\section{Study area and sampling procedure}

The Nireco River was sampled during three consecutive years, corresponding to December 2009 and December 2010, and the post-ash event in November 2011. The river system was divided into three sections: (1) upper section with two sample sites, immersed in a closed forest of Coihue (Nothofagus dombeyi) and Lenga (Nothofagus pumilio) and a bottom river characterized by cobble, pebble and sand; (2) middle section with three sample sites, surrounding an open forest of Coihue and shrubs of Nire (Nothofagus antarctica) and the introduced Rosa mosqueta (Rosa rubiginosa); and (3) outlet section with one sample site, located within disturbed areas directly affected by the urban settlement of San Carlos de Bariloche city. For each site, water temperature, conductivity, total dissolved solids, $\mathrm{pH}$ and dissolved oxygen were measured with a multi-parameter HANNA I-9828 probe. The amount of shaded water surface (canopy cover) was measured using a densiometer (Wildco1), and categorized following the Rapid Bioassessment Protocols (Barbour et al., 1999).

Quantitative sampling was performed using a Surber net of $0.09 \mathrm{~m}^{2}$ surface area and $250 \mu \mathrm{m}$ mesh size with three replicates per site. Chironomid larvae were identified by preparing permanent slides, clearing specimens with $10 \% \mathrm{KOH}$; neutralization with glacial acetic acid; dehydration in 80, 96 and $100 \%$ ethanol and mounting in Canada balsam. Identification of larvae was performed using the following keys and papers: Brundin (1966); Cranston and Edward (1999); Epler (2001); Cranston 
Table 1. Environmental characterization of Nireco River, Río Negro, Argentina during the study period. Mean values \pm SD (Upper section, $n=2$; Middle section, $n=3$; Outlet section, $n=1$ ).

\begin{tabular}{|c|c|c|c|c|c|c|c|c|c|}
\hline & \multicolumn{3}{|c|}{ UPPER } & \multicolumn{3}{|c|}{ MIDDLE } & \multicolumn{3}{|c|}{ OUTLET } \\
\hline & 2009 & 2010 & 2011 & 2009 & 2010 & 2011 & 2009 & 2010 & 2011 \\
\hline Altitude (m a.s.l) & & 1380 & & & 1029 & & & 767 & \\
\hline Canopy cover (light penetration \%) & & (Shaded) & & $70(\mathrm{~Pa}$ & rtly shaded & & & 0 (Open) & \\
\hline $\mathrm{DO}\left(\mathrm{mg} \cdot \mathrm{L}^{-1}\right)$ & $11.31 \pm 0.2$ & $10.7 \pm 0.3$ & 10.1 & $12.38 \pm 0.7$ & $12.3 \pm 1.5$ & 12.2 & $11.3 \pm 0.5$ & 12 & 11.4 \\
\hline $\mathrm{pH}$ & $7.9 \pm 0.01$ & $7.98 \pm 0.2$ & 7.2 & $7.75 \pm 0.1$ & $7.2^{-}$ & 7 & $7.69 \pm 0.02$ & $7.54 \pm 0.02$ & 7 \\
\hline Water temperature $\left({ }^{\circ} \mathrm{C}\right)$ & $4.42 \pm 1.5$ & $4.07 \pm 0.6$ & 3.07 & $6.51 \pm 0.9$ & 7.5 & 4.05 & $8.65 \pm 2$ & $12.6 \pm 0.5$ & 8.5 \\
\hline Conductivity $\left(\mu \mathrm{s} . \mathrm{cm}^{-1}\right)$ & $38.5 \pm 3.2$ & $26.5 \pm 3$ & 33 & $52 \pm 5.7$ & $33.3 \pm 2$ & 42 & $70 \pm 0.5$ & $55 \pm 2.3$ & 66 \\
\hline TDS (ppm) & $15 \pm 1.5$ & $13.5 \pm 3$ & 19 & $25.7 \pm 3.4$ & $17 \pm 7.2$ & 30 & $35 \pm 3$ & $27 . \overline{5} \pm 1$ & 42.2 \\
\hline
\end{tabular}

(2010); Cranston and Krosch (2011); Sæther and Cranston (2012) and Mauad et al. (2016). Density of chironomids was calculated from counts of all the individuals of each taxon from the Surber samples and expressing the results as the number of individuals per surface area $\left(\mathrm{m}^{2}\right)$.

\section{Statistical procedure}

To analyze the community structure, the diversity index of Shannon-Weaver $(H)$, evenness Simpson's index $(1-D)$ and equitability $(J)$ were measured. In order to assess significant differences in density, Taxa richness (TR), Shannon diversity and equitability among sites and sampled years, a one-way ANOVA and Fisher's least significant difference (LSD) post hoc test at $P<0.05$ were performed.

Sample sites were compared to assess similarity in taxonomic composition. The taxa matrix corresponding to the presence/abundance of each taxon by sampling station was analyzed using the Bray-Curtis index and the weighted average method (UPGMA (unweighted pair group method with arithmetic mean)) to build the dendrogram. In order to detect the species mainly responsible for the Bray-Curtis dendrogram, between-site groups were determined using a SIMPER analysis (Clarke, 1993).

A principal component analysis (PCA) was conducted to examine the distribution of the chironomid assemblages in the river. An additional PCA allowed us to determine patterns of functional trait composition in the chironomid assemblage. A total of 18 characters were used to perform this analysis, consisting in 16 discrete and two continuous characters. The coding of continuous characters into discrete character states was made according to the gap weighting procedure proposed by Thiele (1993). This method was applied to ensure reproducibility of the character encoding, identifying that there are clear gaps in the characters that justify the discrete states. The gap weighting procedure of Thiele (1993) consists in ranking the original data as an ordered set of characters arranged according to the values of the mean, and then range standardized with the formula:

$$
X_{\mathrm{s}}=\left(\frac{(X-\min )}{(\max -\min )}\right) \times n
$$

where $X$ is the raw datum and $n$ is the maximum number of character states expected to codify the raw data; in our study, we performed 11 possible character states.

An ordination method (linear model) was performed to provide information enabling a more detailed examination of the relationship between the biologically defined traits at pre and post-eruption dates. The information on traits generally includes expert knowledge and various literature sources; the authors then use a "fuzzy coding" approach to quantify traits (Chevenet et al., 1994). In our study, this coding procedure was not necessary, because analyzed traits were strictly morphological and measured from the collected material. In addition, there is a poor knowledge on traits at the genus or species level from chironomids, contrary to other groups of freshwater invertebrates (Serra et al., 2016), so we decided to analyze the functional traits composition strictly on systematic features. We described the functional composition of communities in terms of relative trait abundance, by multiplying the frequency of each category per trait by the relative log-transformed abundances of species at the site. The resulting trait-by-site array contained the relative abundance of each category per trait in each site and was further analyzed (Larsen and Ormerod, 2010; Feio and Dolédec, 2012).

Most of the analyses and graphical outputs were computed using Past version 2.17 (Hammer et al., 2001), except in the case of ordination analyses that required the use of CANOCO 4.5 (ter Braak and Smilauer, 2002).

\section{Results}

\section{Environmental characterization and chironomid composition}

The elevation of the Nireco River falls from 1380 to $767 \mathrm{~m}$ a.s.l. from the source to its mouth, where the river reaches the Nahuel Huapi Lake (Table 1). The substrate type consisted mainly of cobble and pebble. The pH showed neutral to slightly alkaline values. Mean water conductivity and temperature increased from headwaters to the mouth, with values significantly different among the stations at the three sampled years (Kruskal-Wallis test; $P<0.05)$. Dissolved solids content was low in the system; nevertheless, a slight increase could be observed 
Table 2. Presence/absence of Chironomidae taxa, mean values of density (ind. $\mathrm{m}^{-2}$ ), Taxa richness (TR), Shannon $(H)$, Simpson $(1-D)$ and Equitability $(J)$ from Nireco River, Río Negro, Argentina during the study period.

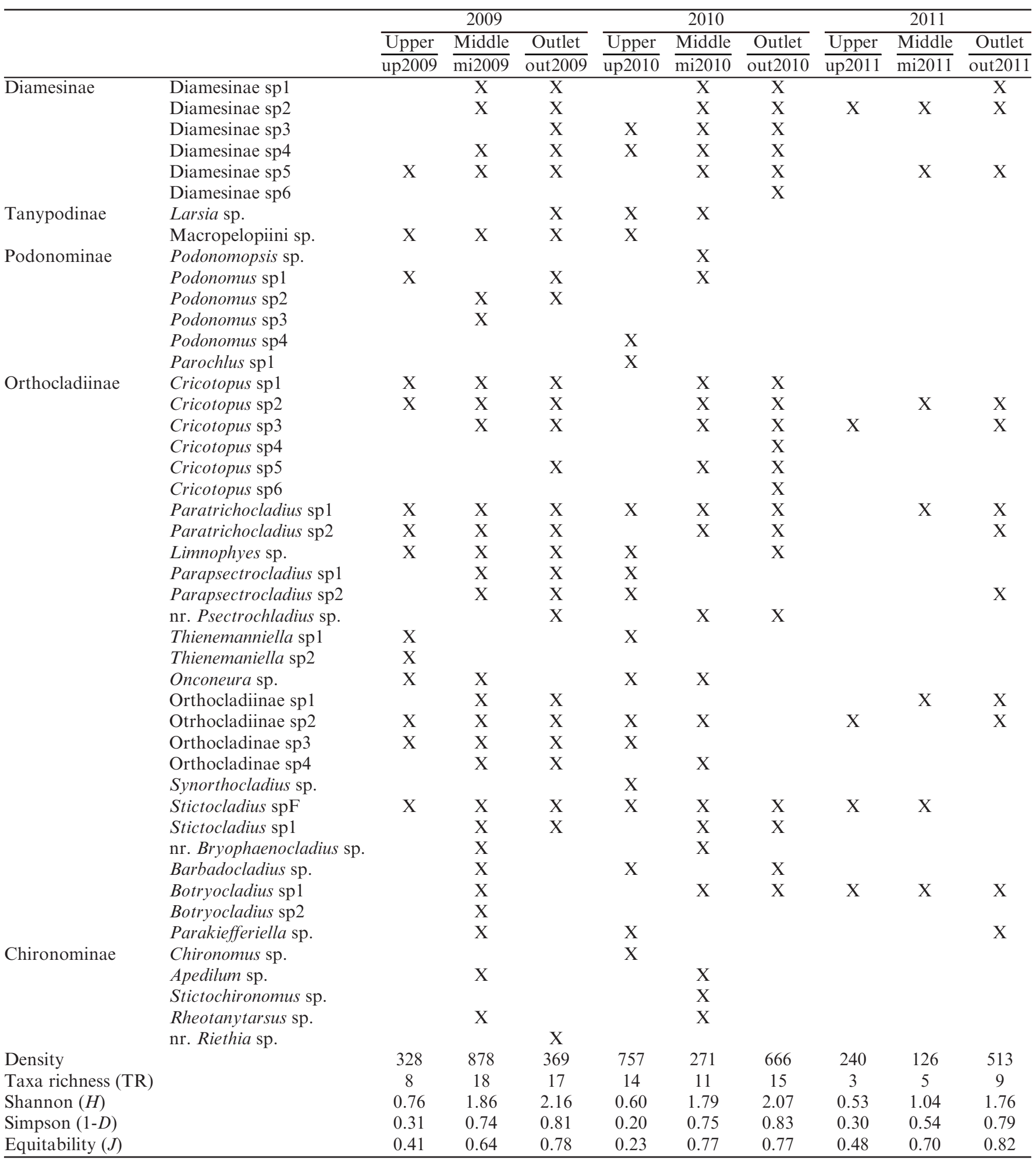

at the outlet section in each year, particularly at post-ash sampled sites. Dissolved oxygen was $>10 \mathrm{mg} . \mathrm{L}^{-1}$ at all the sites during this study.

A total of 2487 individuals were counted (1099 in December 2009, 942 in December 2010, and 445 in November 2011), from which 46 taxa were identified belonging to five subfamilies: Orthocladiinae (27), Diamesinae (6), Podonominae (6), Chironominae (5) and Tanypodinae (2). The highest TR was recorded in December 2010 with 42 taxa (Table 2). An abrupt decrease 
in richness was found after ash deposition (13), where only taxa of the subfamilies Orthocladiinae and Diamesinae were present.

Mechanical alterations in the cephalic capsule were observed in larvae collected after ash deposition. Of a total of 445 individuals collected after ashfall, $12 \%$ showed "rough" edges produced by mechanical wear, breakage or abrasion caused by the ashes accumulated in the substrate. Diamesinae sp2 (31\%), Orthocladiinae sp1 $(25 \%)$ and Botryocladius sp1 $(20 \%)$ were the most affected taxa.

Densities did not show significant differences between sites or years. However, mean TR per year was significantly lower at post-ash samples (ANOVA, $P \leq 0.05$ ), but did not show significant differences between sites. Upper sites had significantly lower values of Shannon diversity and equitability than the other sites (ANOVA, $P \leq 0.05)$.

Concerning diversity assessment, the Shannon diversity index was highest at the outlet section in the three sampled years, with the highest value (2.16 bits) in 2009 . The lowest value $(0.53$ bits) was observed at the upper section of post-ash samples (Table 2). Equitability ranged from 0.23 at the upper section of 2010 to 0.82 at the outlet of the post-ash section (Table 2). From the middle to the outlet of the three sampled years, the values of equitability were higher than 0.6 bits. The sites belonging to the lower section of the basin had equal distribution of individuals. Regarding density, the middle section of post-ash showed the lowest value $\left(126\right.$ ind. $\left.\mathrm{m}^{-2}\right)$; whereas, density in the middle section of 2009 was the highest (878 ind. $\mathrm{m}^{-2}$ ).

From the headwaters to the middle section of the pre-ash sampled sites, an interesting inversion of the density was observed (Fig. 2). An increase of abundance was found in 2009 (upper 2009 with 328 ind. $\mathrm{m}^{-2}$ and middle 2009 with 879 ind. ${ }^{-2}$ ), whereas a decrease was found in 2010 (upper 2010 with 758 ind. $\mathrm{m}^{-2}$ and middle 2010 with 271 ind. $\mathrm{m}^{-2}$ ). Eleven exclusive species were collected from upper 2010, with four of them found in the middle section.

Cluster analysis showed a cophenetic correlation value of 0.78 (Fig. 3). Two station groups are recognized, which adjust to their spatial location within the basin besides temporal distribution. Group 1 includes post-ash sites. Group 2 contains upper, middle and outlet sites from pre-ash event. SIMPER analysis was used to determine the species making the largest contribution to the dendrogram. Diamesinae sp2 and Botryocladius sp1 characterized Group 1. Diamesinae sp2 was present in the three post-ash sampled sites, although it was also present at middle and outlet sites from pre-ash. In addition, Botryocladius sp1 shared the same pattern as Diamesinae sp2, except for the absence of the species in the outlet sampled site of 2009. Group 2 showed Limnophyes sp. and Onconeura sp. as dominant taxa, although the former species was absent in the middle site from 2010 and the latter species was not present at both pre-ash outlet sites.

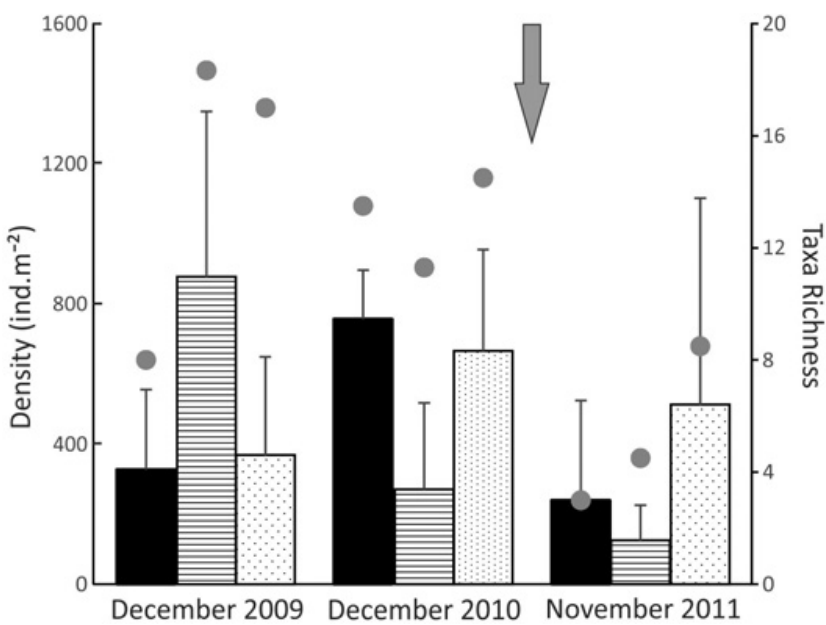

Fig. 2. Mean chironomid density (bars, \pm SD) and species richness (dots) at pre (December 2009, December 2010) and post-eruption (November 2011) dates, Nireco River, Río Negro Province, Argentina (upper section, black column; middle section, line column and outlet section, dots column). The arrow points to the volcano eruption on June 4.

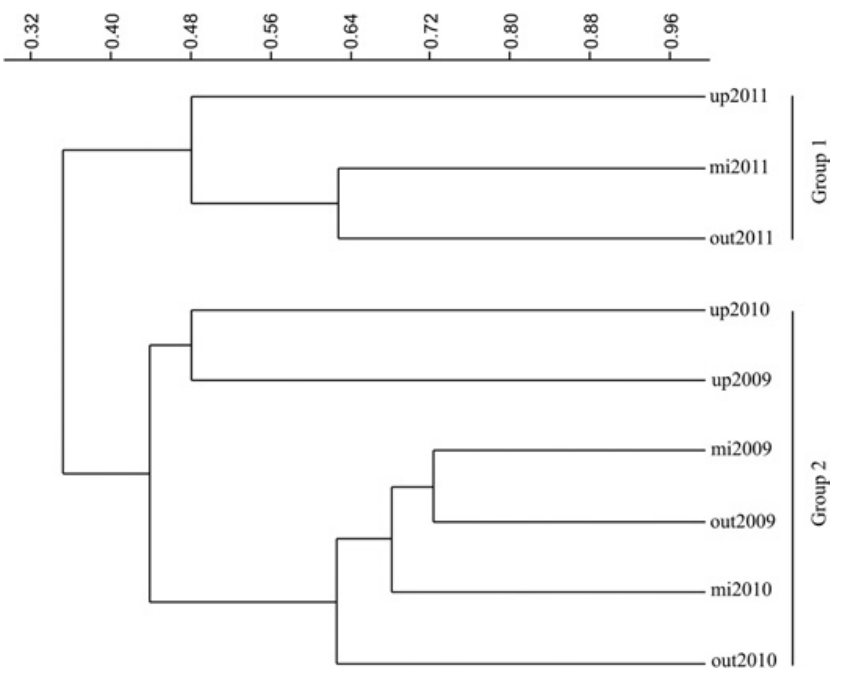

Fig. 3. Cluster of sampling sites according to presence/absence of chironomid taxa in the Nireco River, Río Negro Province, Argentina. Site codes are described in Table 2.

\section{Chironomid ordination}

The distribution of the sample sites over the three sampling periods following PCA of 46 morphotypes is shown in Figure 4(A). The first two axes explained $68 \%$ of the variance in species data for the basin. Podonominae sp1, Podonominae sp4, Parochlus sp., Macropelopiini sp., Larsia sp., Parapsectrocladius sp1, Orthocladiinae sp2, Thienemanniella sp1, Thienemanniella $\mathrm{sp} 2$, Stictocladius $\mathrm{spF}$, Onconeura sp. and Synorthocladius sp. were associated with the upper sites, characterized by areas with low discharge, low temperature and high altitude, except for upper 2011 (post-eruption sampling dates). Sites corresponding to the middle and outlet sections showing 

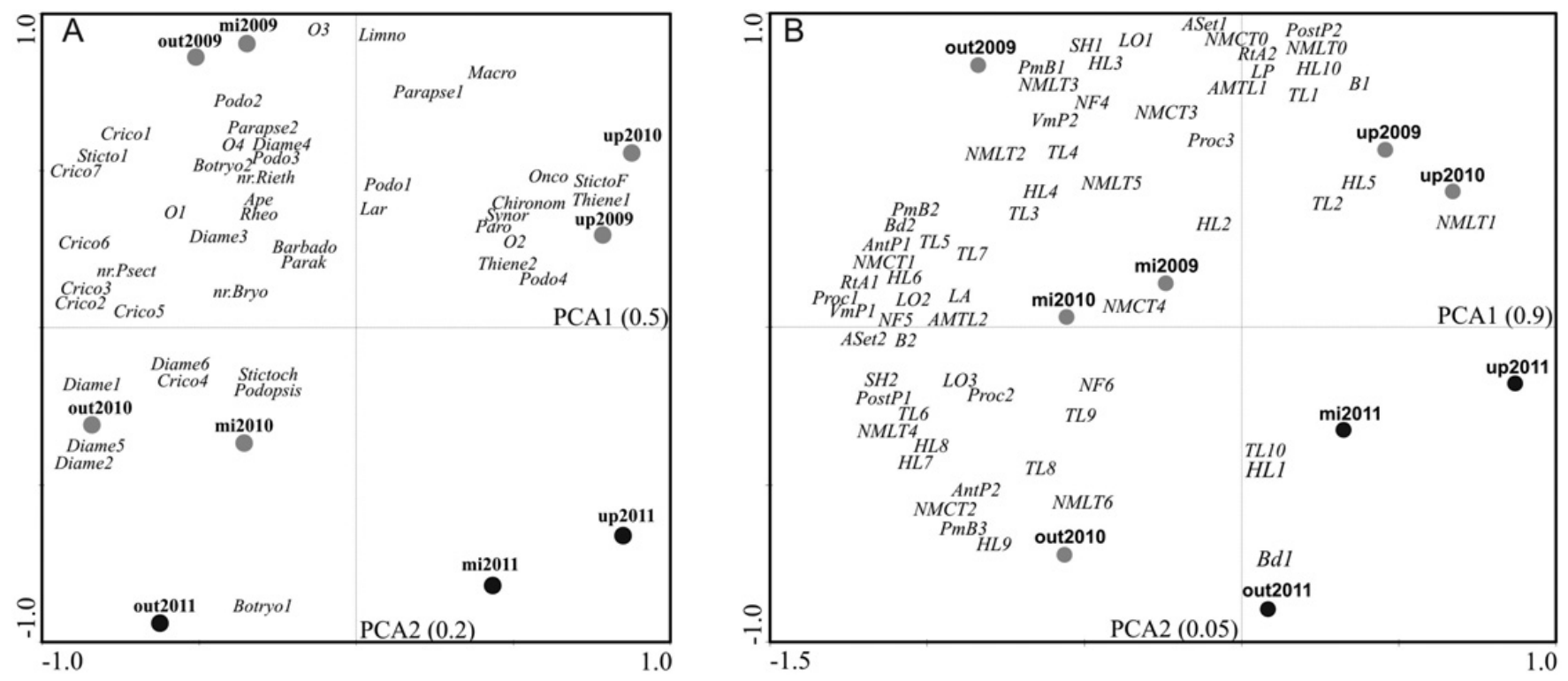

Fig. 4. PCA ordination. Panel (A) shows distribution of the chironomid assemblages in the river, (B) shows trait composition in the Nireco River, Río Negro Province, Argentina. Gray dots correspond to pre-eruption sampling dates, and black dots indicate post-eruption sampling dates. Site codes are described in Table 2. Species and Codes for trait states are described in Tables 3 and 4 , respectively.

more lentic environmental characteristics related to flow and discharge, presented the highest habitat heterogeneity, and displayed the greater amount of species, mostly Orthocladiinae and Chironominae. Conversely, post-eruption sampling dates are only associated with the orthoclad Botryocladius sp1.

Furthermore, the PCA ordination model with 64 traits over pre-eruption and post-eruption sampling dates is shown in Figure 4(B). Traits and their states are detailed in Table 3, while the trait assignments for each chironomid species are shown in Table 4. The first two axes explained $96 \%$ of the variance in trait data for the basin (Fig. 4(B)) and traits were ordered along the second axis, highlighting a disturbance gradient, with pre-eruption sampling dates located toward positive values of axes 2 , and post-eruption dates grouped toward the negative end. Consequently, trait states affected by disturbance were small size (TL1), large head (HL10), abdominal setation (Aset1), welldeveloped posterior parapod (PostP2), well-developed procercus (Proc3), presence of ligula (LP), presence of retractile antenna (RtA2), blade exceeded antennal apex (B1) and apical mandibular tooth length long (AMTL1).

\section{Discussion}

Sediment deposition directly or indirectly affects macroinvertebrate communities by reducing the number of suitable habitats, decreasing substrate stability, reducing food resources and food quality, causing abrasion of the cuticle and mouthparts, or by affecting aquatic respiration due to deposition of silt on respiratory structures (Wiederholm, 1984; Ward, 1992; Broekhuizen et al., 2011;
Jones et al., 2011). Collier et al. (2002) and Broekhuizen et al. (2011) considered the sediment deposited in a stream as a negative predictor, which influences the density of some invertebrates by diminishing the quality of algal food supply or interfering with digestive processes by ingestion of ash. Our results showed that the eruption of the Puyehue-Cordón Caulle Volcanic Complex in the Nireco basin affected the chironomid assemblage, with changes in the taxonomic richness and density (the former community metric being statistically significant and the latter non-significant) associated with the ashfall event. In particular, a notable decrease in chironomid species 5 months after the eruption is shown in our work. This is in agreement with other studies elsewhere in the world (Edwards and Schwartz, 1981; Brusven and Horning, 1984; Anderson, 1992; Edwards and Sugg, 2005; Esin and Sorokin, 2015), and also in Patagonia in the area affected by the Chaiten volcanic event in May 2008 (Miserendino et al., 2012) and also by Puyehue (Lallement et al., 2014). Subfamilies such as Podonominae (Podonomopsis sp., Podonomus sp. and Parochlus sp.), Tanypodinae (Larsia sp. and Macropelopiini sp.) and Chironominae (Chironomus sp., Apedilum sp., Stictochironomus sp., Rheotanytarsus sp. and nr. Riethia sp.) were absent probably due to the disturbance that took place during their larval stage and to a decrease in the quality of their main food supply. The survival likelihood of larvae in the impacted environment is related to how the ashfall affected the provision of food, the composition of suitable substrates, and the amount of suspended solids (Jones et al., 2011; Buendia et al., 2013). Five months after the Puyehue eruption occurred, 13 taxa were collected, with Diamesinae sp1, Diamesinae sp2, Diamesinae sp5, Cricotopus sp2, Cricotopus sp3, Cricotopus sp6 and 
Table 3. Description of the 18 traits (64 states) for all chironomid taxa considered in this study. The letter in each code refers to the trait and the number assigned to the trait state.

\begin{tabular}{|c|c|c|c|}
\hline & Trait & Trait state & Code \\
\hline \multirow[t]{24}{*}{ Head } & Shape & Conical & SH1 \\
\hline & & Rounded & $\mathrm{SH} 2$ \\
\hline & Head length & & HL1-HL10 \\
\hline & Number of mentum central teeth & & NMCT0-NMCT4 \\
\hline & Number of mentum lateral teeth & & NMLT0-NMLT6 \\
\hline & Beard & Absent & $\mathrm{Bd} 1$ \\
\hline & & Present & $\mathrm{Bd} 2$ \\
\hline & Premandibular brush development & Slight & PmB1 \\
\hline & & Moderate & PmB2 \\
\hline & & Developed & PmB3 \\
\hline & Ventromental plate development & Not extended beyond mentum & $\mathrm{VmP1}$ \\
\hline & & Extended beyond mentum & $\mathrm{VmP2}$ \\
\hline & Apical mandibular tooth length & Long & AMTL1 \\
\hline & & Short & AMTL2 \\
\hline & Ligula & Absent & LA \\
\hline & & Present & LP \\
\hline & Retractile antenna & Absent & RtA1 \\
\hline & & Present & RtA2 \\
\hline & Blade & Exceeded antennal apex & B1 \\
\hline & & Not exceeded antennal apex & $\mathrm{B} 2$ \\
\hline & Number of flagelomeres & & NF4-NF6 \\
\hline & Lauterborn organ & Absent & LO1 \\
\hline & & Indistinct & $\mathrm{LO} 2$ \\
\hline & & Developed & LO3 \\
\hline \multirow[t]{10}{*}{ Body } & Total length & & TL1-TL10 \\
\hline & Anterior parapod & Not developed & AntP1 \\
\hline & & Developed & AntP2 \\
\hline & Posterior parapod & Not developed & PostP1 \\
\hline & & Developed & PostP2 \\
\hline & Abdominal setation & Present & ASt1 \\
\hline & & Absent & ASt2 \\
\hline & Procercus development & Slight & Proc1 \\
\hline & & Moderate & Proc2 \\
\hline & & Developed & Proc3 \\
\hline
\end{tabular}

Stictocladius $\mathrm{spF}$ as the most abundant taxa. Considering that many species of Chironomidae are deposit feeders and pool inhabitants, it was not surprising that the group was clearly affected by the ashfall. These results are consistent with those reported by Anderson (1992) after the Mt Saint Helen's episode, which showed chironomids as the dominant taxa at streams and water bodies near the volcano.

A decrease in chironomid abundance in the middle section of the river was observed during the pre-ash years, probably related to precipitation and temperatures as seen in Figure 5. A previous study, also conducted in the Nireco stream, demonstrated that abiotic factors such as seasonality, temperature and current velocity, determine the assemblage of chironomid (Mauad et al. 2016). Precipitations were distributed in different ways along the three sampling years, the peak of precipitation in 2009 occurred in August and October, while for 2010 precipitations were lower and more homogenous. Regarding the mean temperature, a gradual increase from July of 2009 is noticeable; however, for 2010 the increase is more abrupt and began in August. The development of annual average temperatures and precipitation probably affect the composition of chironomids when snow-melting begins and insect activity increases. It is well known that temperature, among other factors such as food availability and photoperiod, may play an important role in the growth and development of chironomids (Rossaro, 1991; Armitage et al., 1995).

Cluster analysis yielded a particular arrangement of the sampling sites, showing a shift in faunal composition at the different sampled years (Fig. 3). Two main groups were recognized; group 1 includes post-ash sampled sites and was characterized by the presence of Diamesinae sp2 and Botryocladius sp1. Furthermore, as revealed by the ordination method, the assemblages between pre- and post-eruption dates were markedly different. Sites corresponding to post-eruption dates were only associated with Botryocladius sp1. The distribution of chironomids in the Nireco River seemed to be affected mainly by the temporary heterogeneity influenced by the volcanic eruption, since in a previous study (Mauad et al. 2016) the distribution of sites and species showed a topographic gradient governed by elevation, indicating stronger rela- 
Table 4. Trait matrix for chironomid taxa. Trait abbreviations and descriptions are provided in Table 3.

\begin{tabular}{|c|c|c|c|c|c|c|c|c|c|c|c|c|c|c|c|c|c|c|c|}
\hline & & TL & $\mathrm{HL}$ & NMCT & NMLT & $\mathrm{PmB}$ & $\mathrm{Bd}$ & $\overline{\mathrm{HS}}$ & $\overline{\mathrm{VmP}}$ & $\overline{\mathrm{RtA}}$ & & $\mathrm{NF}$ & $\mathrm{LO}$ & AMTL & $\mathrm{L}$ & $\overline{\text { AntP }}$ & PostP & $\mathrm{ASt}$ & $\overline{\text { Proc }}$ \\
\hline Diamesinae sp1 & Diame1 & 9 & 8 & 2 & 8 & 3 & 2 & 2 & 1 & 2 & 2 & 5 & 2 & 2 & 2 & 1 & 1 & 2 & 1 \\
\hline Diamesinae sp2 & Diame2 & 7 & 7 & 2 & 6 & 3 & 2 & 2 & 1 & 2 & 2 & 5 & 2 & 2 & 2 & 1 & 1 & 2 & 1 \\
\hline Diamesinae sp3 & Diame3 & 7 & 8 & 1 & 5 & 3 & 2 & 2 & 1 & 2 & 2 & 5 & 2 & 2 & 2 & 1 & 1 & 2 & 1 \\
\hline Diamesinae sp4 & Diame4 & 7 & 7 & 1 & 7 & 3 & 2 & 2 & 1 & 2 & 2 & 5 & 2 & 2 & 2 & 2 & 1 & 2 & 2 \\
\hline Diamesinae sp5 & Diame5 & 10 & 9 & 2 & 6 & 3 & 2 & 2 & 1 & 2 & 2 & 5 & 2 & 2 & 2 & 2 & 1 & 2 & 2 \\
\hline Diamesinae sp6 & Diame6 & 8 & 6 & 2 & 6 & 3 & 2 & 2 & 1 & 2 & 2 & 5 & 2 & 2 & 2 & 2 & 1 & 2 & 2 \\
\hline Larsia sp. & Lar & 5 & 9 & 0 & 0 & 1 & 2 & 1 & 1 & 1 & 2 & 5 & 1 & 1 & 1 & 2 & 2 & 2 & 3 \\
\hline Macropelopiini sp. & Macro & 10 & 11 & 0 & 0 & 1 & 2 & 2 & 1 & 1 & 2 & 5 & 1 & 1 & 1 & 1 & 2 & 1 & 2 \\
\hline Podonomopsis sp. & Podopsis & 4 & 4 & 1 & 8 & 1 & 2 & 1 & 1 & 2 & 2 & 5 & 1 & 2 & 2 & 2 & 2 & 2 & 2 \\
\hline Podonomus sp1 & Podol & 5 & 5 & 1 & 6 & 1 & 2 & 1 & 1 & 2 & 2 & 4 & 1 & 2 & 2 & 1 & 2 & 1 & 3 \\
\hline Podonomus sp2 & Podo2 & 5 & 4 & 1 & 6 & 1 & 2 & 2 & 1 & 2 & 2 & 4 & 1 & 2 & 2 & 1 & 2 & 1 & 1 \\
\hline Podonomus sp3 & Podo3 & 5 & 4 & 1 & 7 & 1 & 2 & 2 & 1 & 2 & 2 & 4 & 1 & 2 & 2 & 1 & 2 & 1 & 3 \\
\hline Podonomus sp4 & Podo4 & 1 & 3 & 1 & 6 & 1 & 2 & 2 & 1 & 2 & 2 & 4 & 1 & 2 & 2 & 1 & 2 & 1 & 2 \\
\hline Parochlus sp. & Paro & 4 & 3 & 1 & 7 & 1 & 2 & 2 & 1 & 2 & 2 & 4 & 1 & 2 & 2 & 1 & 2 & 1 & 3 \\
\hline Cricotopus sp1 & Crico 1 & 7 & 8 & 1 & 6 & 2 & 2 & 2 & 1 & 2 & 2 & 5 & 3 & 2 & 2 & 1 & 1 & 2 & 1 \\
\hline Cricotopus sp2 & Crico2 & 7 & 7 & 1 & 6 & 2 & 2 & 2 & 1 & 2 & 2 & 5 & 3 & 2 & 2 & 1 & 1 & 2 & 1 \\
\hline Cricotopus sp3 & Crico3 & 9 & 7 & 1 & 6 & 2 & 2 & 2 & 1 & 2 & 2 & 5 & 3 & 2 & 2 & 1 & 1 & 2 & 1 \\
\hline Cricotopus sp4 & Crico4 & 8 & 8 & 2 & 6 & 2 & 2 & 2 & 1 & 2 & 2 & 5 & 3 & 2 & 2 & 1 & 1 & 2 & 1 \\
\hline Cricotopus sp5 & Crico5 & 7 & 5 & 1 & 6 & 2 & 2 & 2 & 1 & 2 & 2 & 5 & 3 & 2 & 2 & 1 & 1 & 2 & 1 \\
\hline Cricotopus sp6 & Crico6 & 6 & 6 & 1 & 6 & 2 & 2 & 2 & 1 & 2 & 2 & 5 & 3 & 2 & 2 & 1 & 1 & 2 & 1 \\
\hline Cricotopus sp7 & Crico7 & 7 & 7 & 1 & 6 & 2 & 2 & 2 & 1 & 2 & 2 & 5 & 3 & 2 & 2 & 1 & 1 & 2 & 1 \\
\hline Limnophyes sp. & Limno & 1 & 6 & 2 & 5 & 2 & 2 & 1 & 1 & 2 & 1 & 5 & 2 & 2 & 2 & 1 & 1 & 2 & 1 \\
\hline Parapsectrocladius sp1 & Parapse1 & 5 & 3 & 2 & 5 & 1 & 2 & 2 & 1 & 2 & 2 & 5 & 3 & 2 & 2 & 1 & 1 & 2 & 1 \\
\hline Parapsectrocladius sp2 & Parapse2 & 5 & 4 & 2 & 5 & 1 & 2 & 2 & 1 & 2 & 2 & 5 & 3 & 2 & 2 & 1 & 1 & 2 & 1 \\
\hline nr.Psectrochladius sp. & nr.Psectro & 7 & 7 & 1 & 6 & 1 & 2 & 2 & 1 & 2 & 2 & 5 & 2 & 2 & 2 & 1 & 2 & 2 & 1 \\
\hline Thienemanniella $\mathrm{sp} 1$ & Thiene1 & 1 & 3 & 3 & 3 & 1 & 2 & 2 & 1 & 2 & 2 & 5 & 2 & 2 & 2 & 1 & 2 & 2 & 3 \\
\hline Thienemanniella $\mathrm{sp} 2$ & Thiene2 & 2 & 2 & 1 & 4 & 1 & 2 & 2 & 1 & 2 & 2 & 5 & 2 & 2 & 2 & 1 & 2 & 2 & 3 \\
\hline Onconeura sp. & Onco & 1 & 3 & 3 & 5 & 3 & 2 & 1 & 1 & 2 & 1 & 5 & 3 & 2 & 2 & 1 & 1 & 1 & 1 \\
\hline ladiinae spl & $\mathrm{O} 1$ & 4 & 3 & 3 & 4 & 2 & 2 & 2 & 1 & 2 & 2 & 5 & 2 & 2 & 2 & 1 & 1 & 2 & 1 \\
\hline Otrhocladiinae sp2 & $\mathrm{O} 2$ & 7 & 4 & 1 & 6 & 2 & 2 & 2 & 1 & 2 & 2 & 5 & 3 & 2 & 2 & 1 & 1 & 2 & 1 \\
\hline Orthocladinae sp3 & $\mathrm{O} 3$ & 6 & 3 & 1 & 5 & 2 & 2 & 1 & 2 & 2 & 2 & 5 & 2 & 2 & 2 & 1 & 1 & 2 & 1 \\
\hline Orthocladinae sp4 & O4 & 5 & 4 & 1 & 5 & 1 & 2 & 1 & 1 & 2 & 2 & 4 & 2 & 2 & 2 & 1 & 1 & 2 & 1 \\
\hline Synorthocladius sp. & Synor & 7 & 6 & 1 & 4 & 2 & 1 & 2 & 1 & 2 & 1 & 5 & 3 & 1 & 2 & 2 & 1 & 1 & 1 \\
\hline Stictocladius $\mathrm{spF}$ & StictoF & 9 & 5 & 2 & 3 & 2 & 2 & 2 & 1 & 2 & 1 & 5 & 2 & 2 & 2 & 1 & 2 & 2 & 1 \\
\hline Stictocladius sp1 & Sticto 1 & 8 & 3 & 1 & 4 & 2 & 2 & 2 & 1 & 2 & 1 & 5 & 2 & 2 & 2 & 1 & 2 & 2 & 1 \\
\hline nr.Bryophaenocladius sp. & nr.Bryo & 6 & 2 & 2 & 5 & 2 & 2 & 2 & 1 & 2 & 2 & 5 & 2 & 2 & 2 & 1 & 1 & 2 & 1 \\
\hline Barbadocladius sp. & Barbado & 6 & 5 & 1 & 6 & 1 & 1 & 2 & 1 & 2 & 2 & 5 & 2 & 2 & 2 & 2 & 1 & 2 & 1 \\
\hline Botryocladius sp1 & Botryo1 & 5 & 4 & 2 & 5 & 2 & 1 & 2 & 1 & 2 & 2 & 5 & 3 & 2 & 2 & 1 & 1 & 2 & 1 \\
\hline Botryocladius sp2 & Botryo 2 & 6 & 4 & 1 & 5 & 2 & 1 & 2 & 1 & 2 & 2 & 5 & 3 & 2 & 2 & 1 & 1 & 2 & 1 \\
\hline Botryocladius sp3 & Botryo3 & 5 & 5 & 2 & 5 & 2 & 1 & 2 & 1 & 2 & 2 & 5 & 3 & 2 & 2 & 1 & 1 & 2 & 1 \\
\hline Parakiefferiella sp. & Parak & 11 & 1 & 1 & 5 & 1 & 2 & 2 & 2 & 2 & 2 & 6 & 2 & 1 & 2 & 1 & 1 & 2 & 1 \\
\hline Chironomus sp. & Chironomus & 4 & 3 & 1 & 6 & 2 & 2 & 2 & 2 & 2 & 2 & 5 & 3 & 2 & 2 & 1 & 1 & 2 & 1 \\
\hline Apedilum sp. & Ape & 4 & 6 & 1 & 6 & 2 & 2 & 2 & 2 & 2 & 2 & 6 & 3 & 2 & 2 & 1 & 1 & 2 & 1 \\
\hline Stictochironomus sp. & Stictochiro & 6 & 6 & 4 & 6 & 1 & 2 & 2 & 2 & 2 & 2 & 6 & 3 & 2 & 2 & 1 & 1 & 2 & 1 \\
\hline Rheotanytarsus sp. & Rheo & 4 & 4 & 1 & 5 & 2 & 2 & 2 & 2 & 2 & 2 & 5 & 3 & 2 & 2 & 1 & 1 & 2 & 1 \\
\hline nr.Riethia sp. & nr.Riethia & 8 & 5 & 2 & 7 & 2 & 2 & 2 & 2 & 2 & 1 & 5 & 3 & 2 & 2 & 1 & 1 & 2 & 1 \\
\hline
\end{tabular}

tionships among sites within an altitudinal gradient than among habitat types.

Assessing functional feeding groups in chironomids is an ambiguous issue. Although the functional group categories are partially based on the morphology of the species, there is considerable flexibility in the mode of feeding among chironomids (Henriques-Oliveira et al., 2003). Many factors, such as larval size, food quality and type of sediment might influence the larval feeding behavior. According to Nessimian and Sanseverino (1998) and Nessimian et al. (1999), most chironomids are not restricted to a single feed mode and changes in the feeding habits of chironomids are dependent on environmental conditions as well. In addition to this, changes in the larval diet reflect differences in the structure and composition of the substrates regarding the quality of the available resources (Henriques-Oliveira et al., 2003). This variation in the diet may suggest that chironomids present a low degree of selectivity, having more generalist and opportunistic habits, feeding on what is available at that moment. Besides this, chironomid larvae at different developmental stages often have different dietary requirements (Ingvason et al., 2004). Therefore, we consider that it was not appropriate to include the functional feeding groups in our analyses of the traits, because we are convinced that this is a questionable subject. 


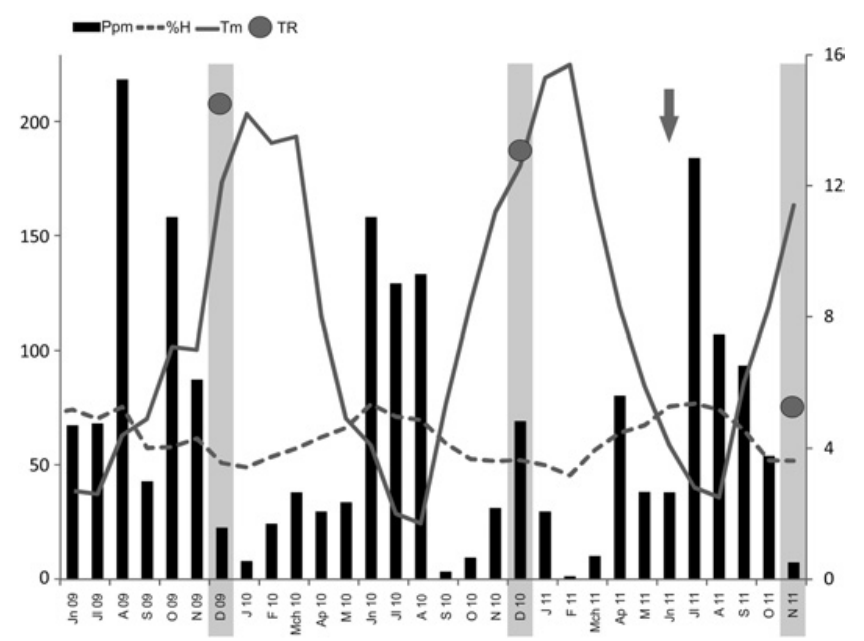

Fig. 5. Mean monthly values from June 2009 to November 2011 of precipitation (dark bars), percentage of humidity (dashes line), temperature (continuous line) and mean species richness (dots). Gray areas represent sampled dates. Climatic data were obtained from: http://www.tutiempo.net/tiempo/Bariloche_Aerodrome/ SAZS.htm. The arrow points to the volcano eruption on June 4.

As a result of our analyses based on morphological traits, the trait states negatively affected by disturbance were small size, large head, presence of abdominal setation, well-developed posterior parapods, well-developed procercus, presence of ligula, presence of retractile antenna, blade exceeded antennal apex and long apical mandibular tooth. A type of mandible with prominent apical tooth and diminishing number of inner mandibular teeth is found in the majority of species within Tanypodinae, which are usually considered to be predators (Olafsson, 1992). Other adaptations to predaceous habits are the retractile antennae and long prolegs, present in the Tanypodinae subfamily. The retractile antenna could be affected by ash deposition since the sensorial structures present become subject to abrasion. The long prolegs are related to rapid motion (Smith, 1989). Buendia et al. (2013) found that mobile and streamlined forms were able to tolerate sedimentation by moving out of the impaired areas. Thus far, morphological traits assessed were grouped as those related to feeding habits and locomotion. The remaining features (antennal blade, procercus and abdominal setation) could be linked to sensorial functions.

Food availability, sediment characterization and interspecific interactions are considered the most important factors governing chironomid larval distribution (Vodopich and Cowell, 1984). Ash deposition affects food availability by reducing light penetration, hence algal growth. Moreover, fine sediment fills up interstitial spaces, reducing the available microhabitats where prey can take refuge from chironomid predation. In general, simple habitats are associated with lower numbers of species than complex habitats. Thus, these factors mentioned above, along with other more general conditions, are inevitably linked to interspecific interactions. Our study suggests that changes of these factors due to the volcanic eruption could favor survival of those species with trait profiles that allow them to tolerate heavy sediment deposition. The species Cricotopus sp6, Orthocladiinae sp1, Orthocladiinae sp2, Stictocladius $\mathrm{spF}$, Botryocladius sp1, Diamesinae sp3 and Diamesinae sp5, are large sized and considered to be collectors and opportunistic omnivorous, ingesting a wide variety of food items (Henriques-Oliveira et al., 2003), and they proved to be the most resilient to this kind of disturbance.

Vandewalle et al. (2010) analyzed morphological metrics from collembola and carabids, showing that these functional descriptors influenced the shift at the landscape scale. In general, traits related to morphological features and life history are clearly the most responsive to sediment impairment (Statzner et al., 2004; Dolédec et al., 2011; Buendia et al., 2013; Brand and Miserendino, 2014). Therefore, a greater description could be encouraged by considering ecological traits in future studies. Our results highlight the significant effort that is still needed to understand the behavior, physiology and ecological tolerances of Chironomidae species. As Serra et al. (2016) showed, chironomids are indeed a rather diverse group with different ecological requirements and characteristics, and they have the potential to improve the signals provided by ecological assessment tools, either in taxonomic assessments or in indirect functional assessments using multiple traits approaches.

\section{Conclusions}

Our results reveal that heavy ash deposition caused high mortality and compositional changes in the chironomid fauna. Since volcanism is a frequent phenomenon in the region (Vigliano et al., 2011), the aim of this paper was to contribute to a better understanding of the disturbance on aquatic environments related to sedimentation processes produced by natural causes. We believe that continued monitoring of the stream would allow for a better understanding of the process, not only in relation to volcanism, but also with regards to other natural or anthropogenic disturbances.

Acknowledgements. We thank the two anonymous reviewers for their valuable comments that greatly improved the manuscript. We would also like to thank NASA's Earth Observatory, which provided the photograph of the Puyehue-Cordón Caulle Volcanic Complex eruption. This study was supported by the Consejo Nacional de Investigaciones Científicas y Técnicas (CONICET), Argentina. This is scientific contribution No. 991 from the Institute of Limnology "Dr Raúl A. Ringuelet" (CONICET, UNLP).

\section{References}

Anderson N.H., 1992. Influence of disturbance on insect communities in Pacific Northwest streams. Hydrobiologia, 248, 79-92. 
Armitage P., Cranston P.S. and Pinder L.C.V., 1995. The Chironomidae. The Biology and Ecology of Non-Biting Midges, London: Chapman \& Hall, 572 p.

Barbour M.T., Gerritsen J., Snyder B.D. and Stribling J.B., 1999. Rapid Bioassessment Protocols for Use in Streams and Wadeable Rivers: Periphyton, Benthic Macroinvertebrates and Fish, Second edn. U.S. Environmental Protection Agency; Office of Water, Washington, DC, 337 p.

Brand C. and Miserendino M.L., 2014. Biological traits and community patterns of Trichoptera at two Patagonian headwater streams affected by volcanic ash deposition. Zool. Stud., 53, 72.

Broekhuizen N., Parkyn S. and Miller D., 2011. Fine sediment effects on feeding and growth in the invertebrate grazers Potamopyrgus antipodarum (Gastropoda, Hydrobiidae) and Deleatidium sp. (Ephemeroptera, Leptophlebiidae). Hydrobiologia, 457, 125-132.

Brundin L., 1966. Transantarctic relationships and their significance, as evidenced by chironomid midges. With a monograph of the subfamilies Podonominae and Aphroteniinae and the Austral Heptagyiae. K. Sven. Vetenskapakadamiens Handl., 11, 1-474.

Brusven M.A. and Horning C.E., 1984. Effects of suspended and deposited volcanic ash on survival and behavior of stream insects. J. Kans Entomol. Soc., 57, 55-62.

Buendia C., Gibbins C.N., Vericat D., Batalla R.J. and Douglas A., 2013. Detecting the structural and functional impacts of fine sediment on stream invertebrates. Ecol. Ind., 25, 184-196.

Chevenet F., Dolédec S. and Chessel D., 1994. A fuzzy coding approach for the analysis of long-term ecological data. Freshwat. Biol., 31, 295-309.

Clarke K.R., 1993. Non-parametric multivariate analysis of changes in community structure. Aust. J. Ecol., 18, 117-143.

Collier K., Parkyn S., Quinn J. and Scarsbrook M., 2002. Bouncing back: how fast can stream invertebrates recolonise? Water Atmosph. NIWA, 9-11.

Cranston P.S., 1995. Introduction. The Chironomidae. In: Armitage P.D., Cranston P.S. and Pinder L.C.V. (eds.), The Biology and Ecology of Non-biting Midges, Chapman \& Hall, Britain, 1-7.

Cranston P.S., 2010. Lucid key to Larval Chironomidae. Available online at: http://keys.lucidcentral.org/keys/v3/ Chironomidae/

Cranston P.S. and Edward D.H.D., 1999. Botryocladius gen. n.: a new transantarctic genus of Orthocladiine midge (Diptera: Chironomidae). Syst. Entomol., 24, 305-333.

Cranston P.S. and Krosch M.N., 2011. Barbadocladius Cranston \& Krosch, a New Genus of Orthocladiinae (Diptera: Chironomidae) from South America. Neotrop. Entomol., 40, $560-567$.

Dolédec S., Phillips N. and Townsend C., 2011. Invertebrate community responses to land use at a broad spatial scale: trait and taxonomic measures compared in New Zealand rivers. Freshwat. Biol., 56, 1670-1688.

Edwards J.S. and Schwartz L.M., 1981. Mount St. Helens ash: a natural insecticide. Can. J. Zool., 59, 714-715.

Edwards J.S. and Sugg P.M., 2005. Arthropods as pioneers in the regeneration of life on the pyroclastic-flow deposits of Mount St. Helens. In: Dale V.H., Swanson F.J. and Crisafulli C.M. (eds.), Ecological Responses to the 1980 Eruption of Mount St. Helens, Springer, New York, 27-138.
Epler J.H., 2001. Identification Manual for the larval Chironomidae (Diptera) of North and South Carolina. A Guide to the Taxonomy of the Midges of the Southeastern United States, Including Florida. Special Publication SJ2001SP13. North Carolina. Department of Environment and Natural Resources, Raleigh, NC, and St. Johns River Water Management District, Palatka, FL, 526 p. http://home. earthlink.net/ johnepler/index.html

Esin E.V. and Sorokin Y.V., 2015. Effect of volcanism on environmental conditions and fauna in rivers of Eastern Kamchatka (using the example of watercourses flowing from Kikhpinych Volcano). Inland Water Biol., 8, 352-365.

Feio M.J. and Dolédec S., 2012. Integration of invertebrate traits into predictive models for indirect assessment of stream functional integrity: a case study in Portugal. Ecol. Indicators, 15, 236-247.

Gaitán J.J., Ayesa J.A., Umaña F., Raffo F. and Brand D.B., 2012. Cartografía del área afectada por la ceniza del volcán Puyehue en Río Negro y Neuquén. XIX Congreso Latinoamericano de la ciencia del suelo, XXIII Congreso Argentino de la ciencia del suelo.

Gallardo B., Gascón S., Quintanta X. and Comín F.A., 2011. How to choose a biodiversity Indicator redundancy and complementarity of biodiversity metrics in a freshwater ecosystem. Ecol. Indicators, 11, 1177-1184.

García P.E. and Añón Suarez D., 2007. Community structure and phenology of chironomids (Insecta: Chironomidae) in Patagonian Andean stream. Limnology, 37, 109-117.

Hammer Ø., Harper D.A.T. and Ryan P.D., 2001. PAST: Paleontological statistics software package for education and data analysis. Palaeontol. Electron. 4, 1-9.

Henriques-Oliveira A.L., Nessimian J.L. and Dorvillé L.F.M., 2003. Feeding habits of chironomid larvae (Insecta: Diptera) from a stream in the Floresta Da Tijuca, Rio de Janeiro, Brazil. Braz. J. Biol., 63, 269-281.

Ingvason H.R., Olafsson J.S. and Gardarsson A., 2004. Food selection of Tanytarsus gracilentus larvae (Diptera: Chironomidae): an analysis of instars and cohorts. Aquat. Ecol., 38, 231-237.

Jones J.I., Murphy J.F., Collins A.L., Sear D.A., Naden P.S. and Armitage P.D., 2011. The impact of fine sediment on macroinvertebrates. River Res. Appl., 28, 1055-1071.

Lallement M.E., Juárez S.M., Macchi P.J. and Vigliano P.H., 2014. Puyehue Cordón-Caulle: post-eruption analysis of changes in stream benthic fauna of Patagonia. Ecol. Aust., 24, 64-74.

Larsen S.E. and Ormerod S.J., 2010. Combined effects of habitat modification on trait composition and species nestedness in river invertebrates. River Res. Appl., 143, 2638-2646.

Mauad M., Miserendino M.L., Risso M.A. and Massaferro J., 2015. Assessing the performance of macroinvertebrate metrics in the Challhuaco-Nireco System (Northern Patagonia, Argentina). Iheringia Sér. Zool., 105, 348-358.

Mauad M., Siri A., Donato M., 2016. Does type of susbstratum affects chironomid larvae composition? A study in a river catchment in Northern Patagonia, Argentina. Neotrop. Entomol., DOI 10.1007/s13744-016-0429-3.

McElravy E.P., Lamberti G.A. and Resh V.H., 1989. Yearto-year variation in the aquatic macroinvertebrate fauna of a northern California stream. J. North Am. Benthol. Soc., 8, $51-63$. 
Mc Dowall R., 1996. Volcanism and freshwater fish biogeography in the northeastern North Island of New Zealand. $J$. Biogeogr., 23, 139-148.

Mcgill B.J., Enquist B.J., Weiher E. and Westoby M., 2006. Rebuilding assemblage ecology from functional traits. Trends Ecol. Evol., 21, 178-185.

Minshall G.W., Robinson C.T., Royer T.V. and Rushforth S.R., 1995. Benthic community structure in two adjacent streams in Yellowstone National Park five years after the 1988 wilfires. Great Basin Nat., 55, 193-200.

Miserendino M.L., Archangelsky M., Brand C. and Epele L.B., 2012. Environmental changes and macroinvertebrate responses in Patagonian streams (Argentina) to ashfall from the Chaitén Volcano (May 2008). Sci. Total Environ., 424, 202-212.

Nessimian J.L. and Sanseverino A.M., 1998. Trophic functional categorization of the chironomid larvae (Diptera: Chironomidae) in a first-order stream at the mountain region of Rio de Janeiro State, Brazil. Verh. Int. Verein. Limnol., 26, 2115-2119.

Nessimian J.L., Sanseverino A.M. and Oliveira A.L.H., 1999. Relações tróficas de larvas de Chironomidae (Diptera) e sua importância na rede alimentar em um brejo no litoral do Estado do Rio de Janeiro. Revta. Brasil. Entomol., 43, $47-53$.

Olafsson J., 1992. A comparative study on mouthpart morphology of certain larvae of Chironomini (Diptera: Chironomidae) with reference to the larval feeding habits. $J$. Zool., 228, 183-204.

Resh V.H., Brown A.V., Covich A.P., Gurtz M.E., Li H.W., Minshall G.W. and Wissmar R.C., 1988. The role of disturbance in stream ecology. J. North Am. Benthol. Soc., 7, 433-455.

Rossaro B., 1991. Chironomids and water temperature. Aquat. Insects, 13, 87-98.

Sæther O.A. and Cranston P.S., 2012. New world Stictocladius Edwards (Diptera: Chironomidae). Neotrop. Entomol., 41, 124-149.

Serra S.R.Q., Cobo F., Graça M.A.S., Dolédec S. and Feio M.J., 2016. Synthesising the trait information of European
Chironomidae (Insecta: Diptera): towards a new database. Ecol. Indicators, 61, 282-292.

Smith K.G.V., 1989. An introduction to the immature stages of British flies: Diptera larvae, with notes on eggs, puparia and pupae. Handbooks Identif. Br. Insects., 10-280.

Statzner B., Dolédec S. and Hugueny B., 2004. Biological trait composition of European stream invertebrate assemblages: assessing the effects of various trait filter types. Ecogeography, 27, 470-488.

ter Braak C.J.F. and Smilauer P., 2002. CANOCO reference manual and CanoDraw for Windows user's guide: software for canonical community ordination (version 4.5). Microcomputer power, Itaca.

Thiele K., 1993. The holy grail of the perfect character: the Cladistic treatment of morphometric data. Cladistics, 9, 275-304.

Townsend C.R., Dolédec S. and Scarsbrook M., 1997. Species traits in relation to temporal and spatial heterogeneity in streams: a test of habitat templet theory. Freshwat. Biol., 37, 367-387.

Vandewalle M., de Bello F., Berg M.P., Bolger T., Dolédec S., Dubs F., Feld C.K., Harrington R., Harrison P.A., Lavorel S., da Silva P.M., Moretti M., Niemelä J., Santos P., Sattler T., Sousa J.P., Sykes M.T., Vanbergen A.J. and Woodcock B.A., 2010. Functional traits as indicators of biodiversity response to land use changes across ecosystems and organisms. Biodivers. Conserv., 19, 2921-2947.

Vigliano P.H., Jones A., Judd A., Planas H. and Lippolt G., 2011. Bottom gas seeps at lake Nahuel Huapi, Patagonia. Rev. Asoc. Geol. Argentina, 68, 481-490.

Vodopich D.S. and Cowell B.C., 1984. Interaction of factors governing the distribution of a predatory aquatic insect. Ecology, 65, 39-52.

Ward J.V., 1992. Aquatic Insect Ecology, Part 1, Biology and Habitat, John Wiley \& Sons, Inc., New York, 456 p.

Wiederholm T., 1984. Responses of aquatic insects to environmental pollution. In: Resh V.H. and Rosenberg D.M. (eds.). The Ecology of Aquatic Insects, New York, 508-557. 